\section{Dikegulac, but Not Benzyladenine, Enhances the Aesthetic Quality of Boston Fern}

\author{
Johnny Carter ${ }^{1}$, Bharat P. Singh ${ }^{2}$, and Wayne Whitehead ${ }^{3}$ \\ Agricultural Research Station, School of Agriculture, Home Economics and \\ Allied Programs, Fort Valley State University, Fort Valley, GA 31030-3298
}

Additional index words. Nephrolepsis exaltata, shoot count, frond length, leaf area, dry weight

\begin{abstract}
Greenhouse studies conducted in 1990 and 1991 evaluated the influence of dikegulac and benzyladenine on frond initiation and vegetative growth of Boston fern [Nephrolepsis exaltata (L.) Schott 'Compacta']. Four weeks after transplanting, fern liners were sprayed with aqueous solutions of dikegulac $\left(0,250,500\right.$, or $\left.750 \mathrm{mg} \cdot \mathrm{L}^{-1}\right)$ or benzyladenine (BA; 0, 50, 100, or $\left.150 \mathrm{mg} \cdot \mathrm{L}^{-1}\right)$. The effect of dikegulac and $B A$ on the number of shoots, frond length, leaf area, and dry weight was measured. Dikegulac stimulated shoot initiation and increased leaf area and dry weight without affecting frond length. BA reduced frond length and had no effect on shoot initiation and dry weight. This study suggests dikegulac has potential to improve the appearance and aesthetic quality of Boston fern. Chemical names used: 2,3:4,6-bis-0-(1-methylethylidene)- $\alpha-\mathrm{L}-\mathrm{Xylo}-2$ hexulofuranosonic acid (dikegulac); $N$-(phenylmethyl)-1H-purine-6-amine (benzyladenine).
\end{abstract}

Ferns in hanging baskets are in high demand for patio and interior decoration. Density of foliage is the main factor contributing to their appearance and aesthetic quality and determines marketability and price. Density of foliage is a result of shoot count and total leaf area. Therefore, increasing these attributes of ferns is a high priority.

Dikegulac (Atrinal; Gordon Corp., Kansas City, Kan.) and benzyladenine (BA) (ProShear; Abbott Lab., Chicago) are commercially marketed plant growth regulators that have successfully modified growth in several plant species (Frost and Kretchman, 1987; Johnson, 1981; Mahotiere et al., 1988; Matta, 1984). Dikegulac application to bougainvillea (Bougainvillea $\times$ buttiana Holtt and Standl) enhanced flowering and aesthetic quality, but did not alter branch count or plant height (Norcini et al., 1992). Al-Juboory and Williams (1991) observed that dikegulac stimulated branching but reduced branch length in golden pothos (Scindapsus aureus L.). Cytokinins affect apical dominance by releasing lateral shoot buds from inhibition (Philips, 1969). They increase shoot count, shoot length, and leaf area in alfalfa (Medicago sativa L.) (Tomkin and Hall, 1991). Applying kinetin directly to buds induced axillary shoot stimu-

\footnotetext{
Received for publication 25 Sept. 1995. Accepted for publication 26 May 1996. Research conducted at Fort Valley Agricultural Research Station, Fort Valley, Ga. Use of trade names does not imply endorsement of the products named nor criticism of similar ones not named. The cost of publishing this paper was defrayed in part by the payment of page charges. Under postal regulations, this paper therefore must be hereby marked advertisement solely to indicate this fact.

${ }^{1}$ Associate Professor.

${ }^{2}$ Professor.

${ }^{3}$ Research Associate.
}

z1990 and 1991 data combined.

${ }^{\mathrm{y}} \mathrm{Q}=$ quadratic.

${ }^{x} \mathrm{Y}=6.9+0.033 \mathrm{x}-0.0 \mathrm{x}^{2}, r^{2}=0.70$

${ }^{\mathrm{w}} \mathrm{Y}=30.3-0.002 \mathrm{x}, r^{2}=0.04$.

${ }^{\mathrm{v}} \mathrm{Y}=1428.6+7.94 \mathrm{x}-0.008 \mathrm{x}^{2}, r^{2}=0.57$.

${ }^{\mathrm{u}} \mathrm{Y}=7.7+0.034 \mathrm{x}-0.0 \mathrm{x}^{2}, r^{2}=0.48$.

Ns, ** Nonsignificant or significant at $P \leq 0.01$, respectively.
Therefore, the present study was carried out to determine the effect of dikegulac and BA on frond initiation and growth of Boston fern.

\section{Materials and Methods}

Greenhouse studies to determine the behavior of dikegulac and BA on Boston fern were conducted at Fort Valley State College Agricultural Research Station in 1990 and repeated in 1991. For all experiments, uniform 70-mm tissue culture fern liners (Fender's Flora, Apopka, Fla.) were transplanted into 1.7-L pots containing Pro-Mix BX 3 sphagnum moss : 1 perlite : 1 vermiculite (by volume); Premier Brand, New Rochelle, N.Y.]. Transplanting was on 7 and 10 Oct. 1990 and 1991, respectively. Each liner consisted of one well-developed shoot. Fertilizer ( $20 \mathrm{~N}-4.4 \mathrm{P}-$ $16.6 \mathrm{~K}$ ) was applied at every watering with $\mathrm{N}$ at $250 \mathrm{mg} \cdot \mathrm{L}^{-1}$. Throughout these experiments, the greenhouse was set at $24{ }^{\circ} \mathrm{C}$ day/ $18{ }^{\circ} \mathrm{C}$ night.

Four weeks after transplanting, the liners were sprayed to drip with aqueous solutions of dikegulac $\left(0,250,500\right.$, or $\left.750 \mathrm{mg} \cdot \mathrm{L}^{-1}\right)$ or BA $\left(0,50,100\right.$, or $\left.150 \mathrm{mg} \cdot \mathrm{L}^{-1}\right)$. Tap water was used as a control. Each treatment was replicated six times with one potted fern liner as an experimental unit arranged on the greenhouse bench in a randomized complete-block design. The experiments were terminated 12 weeks after chemical application. At this time, the plants were cut off at the soil level. Fronds were counted and then bunched and the longest one was measured. Leaf area for each plant was determined with a leaf area meter (model LI-3100; LI-COR, Lincoln, Neb.). The fronds were then dried at $60{ }^{\circ} \mathrm{C}$ for $48 \mathrm{~h}$ to determine dry weight. The experiment $\times$ treatment interaction was nonsignificant; therefore, data from both experiments were combined for statistical analysis. All data were subjected to analysis of variance and regression analysis (SAS Institute, Cary, N.C.).

\section{Results and Discussion}

Dikegulac. Shoot count was significantly increased by dikegulac application (Table 1, Fig. 1); a quadratic equation provided the best fit for the relationship. The linear component of the regression equation predicted shoot count increase by 3.3 for every $100 \mathrm{mg} \cdot \mathrm{L}^{-1}$

Table 1. Effect of dikegulac on shoot count and growth of Boston fern by 12 weeks after treatment. ${ }^{2}$

\begin{tabular}{lcccc}
\hline \hline \multirow{2}{*}{$\begin{array}{l}\text { Dikegulac } \\
\left(\mathrm{mg} \cdot \mathrm{L}^{-1}\right)\end{array}$} & \multicolumn{3}{c}{ Growth characteristics } \\
\cline { 2 - 5 } & $\begin{array}{c}\text { Shoot } \\
(\text { no. })\end{array}$ & $\begin{array}{c}\text { Frond length } \\
(\mathrm{cm})\end{array}$ & $\begin{array}{c}\text { Leaf area } \\
\left(\mathrm{cm}^{2}\right)\end{array}$ & $\begin{array}{c}\text { Dry wt } \\
(\mathrm{g})\end{array}$ \\
\hline 0 & 6.9 & 30.4 & 1440 & 7.7 \\
250 & 13.7 & 30.4 & 2909 & 14.0 \\
500 & 17.0 & 27.6 & 3555 & 15.8 \\
750 & 17.3 & 29.4 & 3146 & 13.1 \\
Significance & $\mathrm{Q}^{* *, \mathrm{x}}$ & $\mathrm{NS}^{\mathrm{w}}$ & $\mathrm{Q}^{* *, \mathrm{v}}$ & $\mathrm{Q}^{* *}, \mathrm{u}$ \\
\hline
\end{tabular}




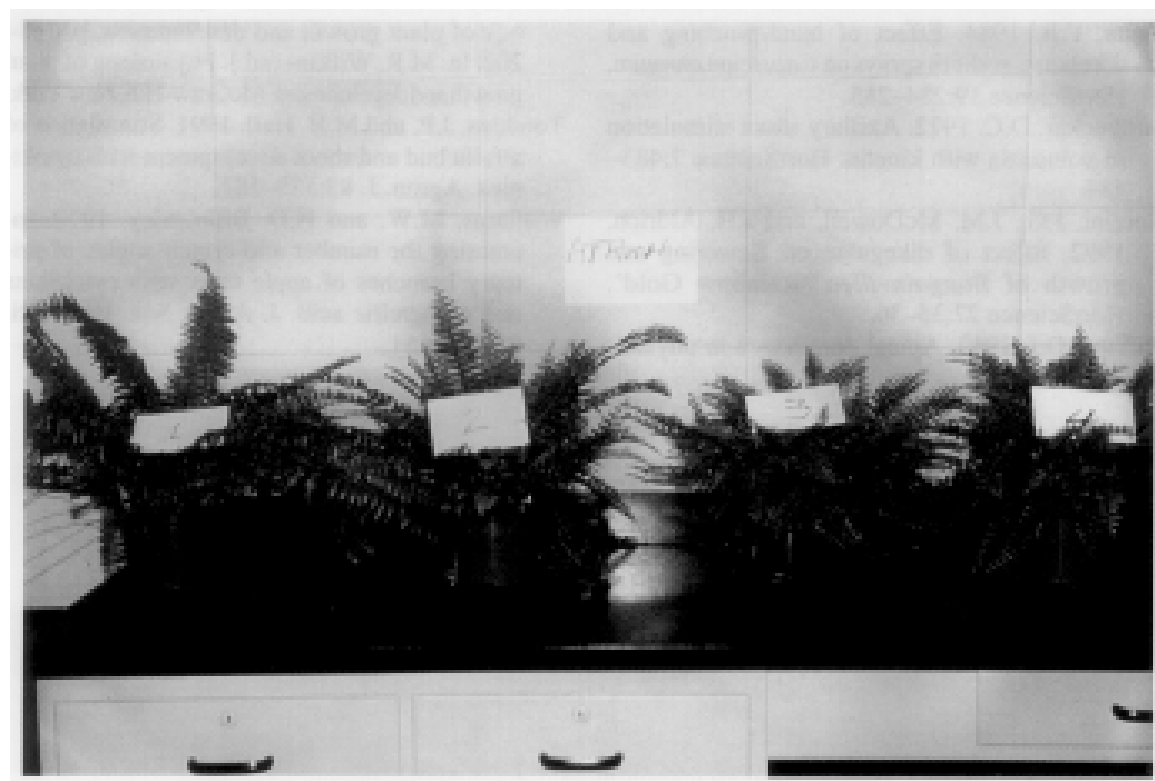

Fig. 1. Effect of dikegulac on the growth of Boston fern [left to right $\left(\mathrm{mg} \cdot \mathrm{L}^{-1}\right): 1=$ nontreated control; dikegulac at $2=250,3=500$, and $4=750]$.

Table 2. Effect of benzyladenine (BA) on shoot count and growth of Boston fern by 12 weeks after treatment. ${ }^{2}$

\begin{tabular}{lcccc}
\hline \hline \multirow{2}{*}{$\begin{array}{l}\text { BA } \\
\left(\mathrm{mg} \cdot \mathrm{L}^{-1}\right)\end{array}$} & $\begin{array}{c}\text { Growth characteristics } \\
\text { Shoot }\end{array}$ & $\begin{array}{c}\text { Frond length } \\
(\mathrm{cm})\end{array}$ & $\begin{array}{c}\text { Leaf area } \\
\left(\mathrm{cm}^{2}\right)\end{array}$ & $\begin{array}{c}\text { Dry wt } \\
(\mathrm{g})\end{array}$ \\
\hline 0 & 8.3 & 33.8 & 1811 & 12.0 \\
50 & 11.3 & 29.4 & 2752 & 14.6 \\
100 & 11.2 & 24.6 & 1995 & 10.8 \\
150 & 10.3 & 29.9 & 2277 & 11.5 \\
Significance $^{\mathrm{y}}$ & $\mathrm{NS}^{\mathrm{x}}$ & $\mathrm{Q}^{* *, \mathrm{w}}$ & $\mathrm{C}^{* *, \mathrm{v}}$ & $\mathrm{NS}^{\mathrm{u}}$ \\
\hline
\end{tabular}

${ }^{\mathrm{z}} 1990$ and 1991 data combined.

${ }^{\mathrm{y}} \mathrm{C}=$ cubic, $\mathrm{Q}=$ quadric.

${ }^{\mathrm{x}} \mathrm{Y}=9.4+0.012 \mathrm{x}, r^{2}=0.06$

${ }^{\mathrm{w}} \mathrm{Y}=34.3-0.18 \mathrm{x}+0.0 \mathrm{x}^{2}, r^{2}=0.40$.

${ }^{v} \mathrm{Y}=1811.2+54.02 \mathrm{x}-0.89 \mathrm{x}^{2}+0.004 \mathrm{x}^{3}, r^{2}=0.21$.

"Y $\mathrm{Y}=13.0-0.01 \mathrm{x}, r^{2}=0.02$.

Ns, ${ }^{*}$ Nonsignificant or significant at $P \leq 0.01$, respectively.

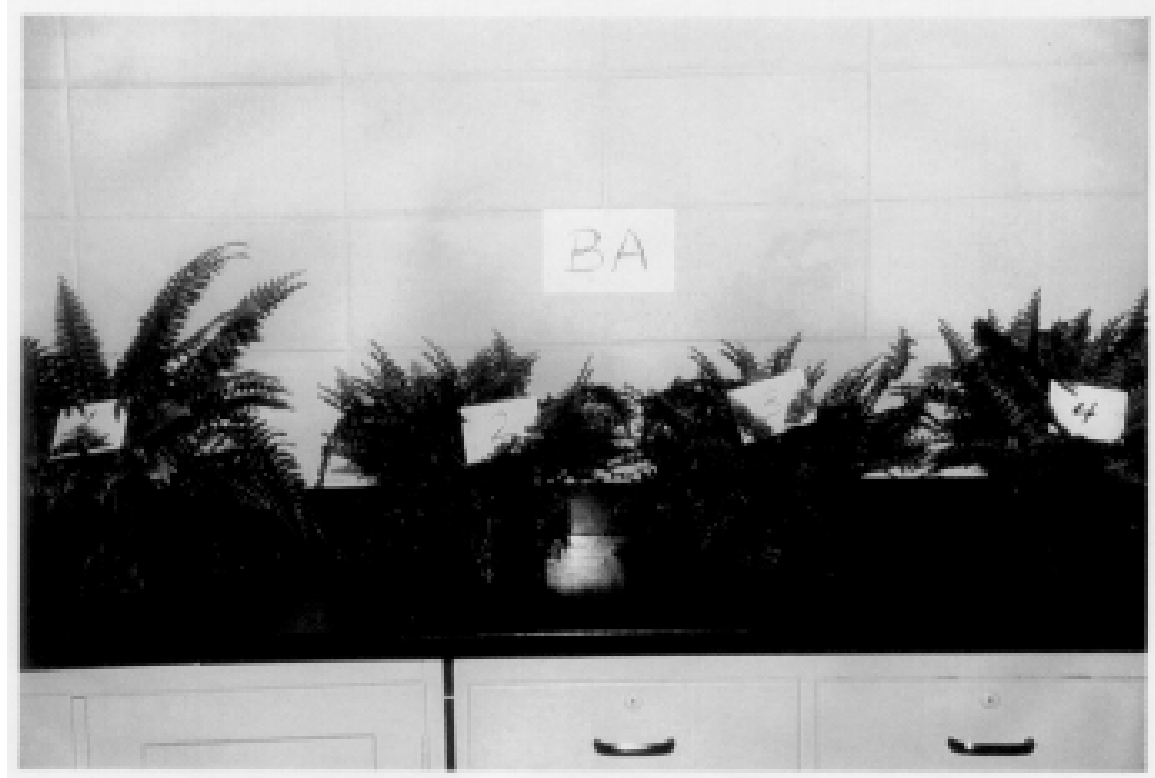

Fig. 2. Effect of benzyladenine (BA) on the growth of Boston fern [left to right $\left(\mathrm{mg} \cdot \mathrm{L}^{-1}\right): 1=$ nontreated control; BA at $2=50,3=100,4=150]$. increase in dikegulac. The $r^{2}$ for the equation indicates that $70 \%$ of the total variation in shoot count was attributable to dikegulac. Frond length was not affected by dikegulac use. These findings concur with previous results indicating dikegulac stimulated shoot emergence, but not plant height (Al-Juboory and Williams, 1991; Carter and Mahotiere, 1991; Mahotiere et al., 1988). Our results, however, disagree with those of Norcini et al. (1992), who reported no dikegulac effect on 'Rainbow Gold' bougainvillea branching.

The response for leaf area development with dikegulac was quadratic (Table 1, Fig. 1). The average increase in leaf area due to dikegulac amounted to $794 \mathrm{~cm} / 100 \mathrm{mg} \cdot \mathrm{L}^{-1}$ in the linear portion of the model, but 750 $\mathrm{mg} \cdot \mathrm{L}^{-1}$ was detrimental to leaf development. The regression of dikegulac on frond dry weight also was quadratic. The increase in dry weight due to more and larger leaves averaged $3.4 \mathrm{~g} /$ $100 \mathrm{mg} \cdot \mathrm{L}^{-1}$ in the linear portion of the model. Our results contrast with those of Mahotiere et al. (1988), who reported a decrease in asparagus fern dry weight following dikegulac application.

Benzyladenine. BA did not affect shoot count in Boston fern (Table 2, Fig. 2). Frond length declined significantly with BA application. There was a cubic increase in leaf area with BA application. However, the regression equation had a low $r^{2}$ value. BA was not effective in increasing fern dry weight. Therefore, cytokinin-induced growth, as noted previously in alfalfa (Tomkins and Hall, 1991), does not hold for Boston fern.

Results from these experiments suggest that dikegulac has potential for improving the appearance and aesthetic quality of Boston fern. Dikegulac increased shoot count, leaf area, and dry weight without decreasing frond length.

\section{Literature Cited}

Al-Juboory, K.H. and D.J. Williams. 1991. Effects of dikegulac-sodium and BA plus GA to enhance lateral branching of golden pothos. PGRSA Quarterly 19:166.

Carter, J. and S. Mahotiere. 1991. Influence of BA, promalin, and dikegulac-sodium on shoot initiation and vegetative growth of caladiums. HortScience 26:684. (Abstr.)

Cody, C.A., F.E. Larson, and R. Fritts, Jr. 1985. Stimulation of lateral branch development in tree fruit nursery stock with $\mathrm{GA}_{4+7}+\mathrm{BA}$. HortScience 20:758-759.

Frost, D.J. and D.W. Kretchman. 1987. Influence of dikegulac on the growth of processing tomatoes. HortScience 22:232-234.

Green, D.W. and W.R. Autio. 1989. Evaluation of benzyladenine as a chemical thinner on 'McIntosh' apples. J. Amer. Soc. Hort. Sci. 14:68-73.

Green, D.W. and P. Miller. 1988. Effects of growth regulator sprays and notching on growth and branching 'Starkrimson Delicious' apple trees. J. Amer. Soc. Hort. Sci. 113:18-23.

Johnson, A.R. 1981. The effects of dikegulacsodium on budbreak increase of Dracaena fragrams. MS Thesis, Univ. of Tennessee, Knoxville.

Keever, G.J., W.J. Foster, J.W. Olive, and M.S. West. 1993. Increasing 'Bradford' pear crotch angles and lateral shoot counts with benzyl- 


\section{Growth Regulators}

adenine or promalin sprays. HortScience 28:678.

Lyons, R.E. and C.L. Hale. 1987. Comparison of pinching methods on selected species of Columnea, Kalanchoe, and Crassula. HortScience 22:72-74.

Mahotiere, S., C. Johnson, and P. Cullers. 1988. Asparagus crown response to dikegulac. HortScience 23:308-309.

Mahotiere, S., C. Johnson, and P. Howard. 1993. Stimulating asparagus seedling shoot production with benzyladenine. HortScience 28:229.
Matta, F.B. 1984. Effect of hand-pinching and dikegulac-sodium sprays on Capsicum annиum. HortScience 19:284-285.

Millbocker, D.C. 1972. Axillary shoot stimulation in poinsettia with kinetin. HortScience 7:483484.

Norcini, J.G., J.M. McDowell, and J.H. Aldrich. 1992. Effect of dikegulac on flowering and growth of Bougainvillea 'Rainbow Gold'. HortScience 27:35-36.

Phillips, D.J. 1969. Apical dominance in physiol- ogy of plant growth and development, p. 163202. In: M.R. Wilkins (ed.). Physiology of plant growth and development. McGraw-Hill, New York.

Tomkins, J.P. and M.H. Hall. 1991. Stimulation of alfalfa bud and shoot development with cytokinins. Agron. J. 83:577-581.

Williams, M.W. and H.D. Billingsley. 1970. Increasing the number and crotch angles of primary branches of apple trees with cytokinins and gibberellic acid. J. Amer. Soc. Hort. Sci. 95:649-651. 